\title{
BOYZ OUT THE HOOD? GEOGRAPHICAL, LINGUISTIC AND SOCIAL MOBILITY IN JOHN SINGLETON'S BOYZ N THE HOOD ${ }^{1}$
}

\author{
ANDRÉS BARTOLOMÉ LEAL \\ University of Zaragoza
}

\begin{abstract}
In contrast with many of the films said to belong to the hood films' cycle of the nineties, John Singleton's Boyz N the Hood (1991) sober and realistically portrays the hardships of blacks' existence in the Los Angeles' neighbourhood of South Central. For the film, as this paper aims to demonstrate, the inability of the hood residents to escape the geographical and social constrains of their environment is a direct outcome of the longdistance control that the mainly white dominant elites exert over their existence. Through the confronting lifestyles that the characters embody, the film exemplifies the different possible attitudes towards the place/race-biased identities that the life in the hood motivates. In order to contest the social determinism that seems to dominate the life of the residents of the hood, Tre's character stands out as epitome of the film's ideology in favour of education and respect, and not violence, as the way to survive this socialpolitical scheme.
\end{abstract}

Keywords: Identity, film, mobility, race, representation, Socio-Pragmatics.

1 Special thanks to Profs. Beatriz Penas Ibáñez and Celestino Deleyto Alcalá for their guidance and support on the present research. 
ANDRÉS BARTOLOMÉ LEAL

\title{
¿CHICOS FUERA DEL BARRIO? MOVILIDAD GEOGRÁFICA, LINGÜÍS- TICA Y SOCIAL EN LOS CHICOS DEL BARRIO DE JOHN SINGLETON
}

\begin{abstract}
RESUMEN. A diferencia de muchas de las peliculas norteamericanas pertenecientes a lo que hoy es conocido como el ciclo de "películas de barrio" de los noventa, Los Chicos del Barrio (1991) de John Singleton representa de una manera sobria y realista las dificultades y conflictos resultantes de la convivencia diaria de la comunidad negra en el barrio angelino de South Central. Para dicha película, como intenta demostrar este trabajo, la incapacidad de los habitantes negros del barrio a la hora de escapar de las limitaciones geográficas y sociales de su entorno, no es sino un resultado directo del control ejercido sobre su existencia por las distantes, y mayoritariamente blancas, élites en el poder. A través de los antagónicos estilos de vida que los diferentes personajes representan, la película ejemplifica las diferentes posibles actitudes hacia las identidades predefinidas en términos de raza y residencia, y mayoritariamente abocadas al desastre, que la vida en el barrio favorece. Con el objetivo de combatir el determinismo social que parece dominar la vida de los residentes en el barrio, el personaje de Tre se erige como epitome de la ideología de la película, a favor de la educación, el respeto mutuo y el rechazo a la violencia como vehiculos para trascender, y sobrevivir, este esquema social.
\end{abstract}

Palabras clave: Identidad, cine, movilidad, raza, representación, SocioPragmática.

At the beginning of the nineties, a cycle of films, later described by critics as "Hood Films", ${ }^{2}$ brought to the surface of the mainstream North American cinema the situation and living conditions of contemporary black urban communities. Mainly focused on the poorest and more conflictive neighbourhoods of big North American metropolitan areas, especially New York and Los Angeles, films like New Jack City (Mario Van Peebles 1991), Menace II Society (Albert and Allen Hughes 1993), Juice (Ernest R. Dickinson 1993) or Fresh (Boaz Yakin 1994) depicted a life surrounded by incessant insecurity, drug trades, prostitution, crime and violence. Most of these films were in fact directed by newcomer black directors, obtaining a public relevance never seen before. Fuelled by Hip-Hop lyrics, and sometimes with rappers in the lead roles, these films along with their

\footnotetext{
2 This term is used to refer to films that portray the difficult coming of age of their black protagonists, placing the narrative always within the geographical boundaries of the low-class black neighborhood (Massood 1996: 85).
} 
soundtracks gained great popularity as a whole, and their representation of black youth had an immense, but not necessarily constructive, social and cultural repercussion. While at first they were regarded positively as signal of an outburst of black relevance and creativity within the North American society, it was not long before they were criticized for their sometimes one-dimensional portrayal of black communities as poor and violent, perpetuating this way negative stereotypical images of blacknesss in the US. ${ }^{3}$

Of the myriad of films said to belong to the aforementioned cycle, none got (or still gets) the critical, spectatorial or academic response that Boyz ' $N$ ' the Hood (John Singleton 1991) did. Described as much more "subtle and complex" than other contemporary black-on-black representations (Michael Eric Dyson 1993: 91), the film portrays the lives of Tre Styles (Desi Arnez Hines II/Cuba Gooding Jr.), a young black man, his friends and family, who live in the conflictive neighbourhood of South Central Los Angeles. Under the tight guidance and discipline of his father Furious (Lawrence Fishbourne), Tre will be able to get a proper education and to avoid being trapped in the self-destructive vicious circle of verbal and physical violence characteristic of the hood, a junglelike society that will not be so benevolent with many of his friends.

Harsh and unsweetened at times, the film's realistic representation of the black neighbourhood's everyday life deliberately avoids both the stylized romantization in which many "hood films" had fallen, as well as the degraded stereotypification of previous white-dominated representations of blackness. ${ }^{4}$ Although present at certain points, neither drugs nor prostitution or guns are dominant motifs within the picture, and when their images appear, they are addressed from a completely non-glorifying perspective as the main liabilities of the lower class black experience. Seemingly aware of the immense ideological power of mainstream popular representations, the film not only avoids any kind of possible exaltation of violence and confrontation as a basic living condition in the 'hood, but also openly traces and criticizes the reasons for the reproduction of this existing social scheme. ${ }^{5}$

\footnotetext{
3 As pointed out by Miles Hewstone and Howard Giles (1997), stereotypes are not negative by definition. Positive stereotypes may serve to highlight or bring to the front the aspects of their identities by which a group or a person wants to be seen and differentiated from others.

4 Within the first group we can find films ranging from Sweet Sweetback's Baadasssss Song (Melvin Van Peebles 1971) to more recent ones like xXx: State of the Union (Lee Tamahori 2005). Of the second, I reckon that there is no need for specific examples, although one might think about The Birth Of a Nation (D.W. Griffith 1915) or Gone With the Wind (Victor Flemming, George Cukor, Sam Wood 1939) as classic examples.

5 As Robyn Wiegman points out, despite the cautious approach of the film towards violence it could not avoid being blamed for "instigating audience violence" (1993: 182).
} 
With all this in mind, and from a socio-pragmatic perspective, this paper will aim to, first: deconstruct the constellation of reasons that are behind the constant climate of violence prevailing in this kind of neighbourhood and second, the role the control over the mobility of its inhabitants fulfils in the perpetuation of the system. A system that, as will be developed, relies on the prevailingly hierarchical asymmetrical relationship between whites and blacks, and the self-destructive confrontation among the latter. As a final statement, this paper will present the character of Tre as a viable departure from this conflictual scheme and as the desirable role model that embodies the film's demythologising ideology around social relations between blacks.

Even before the opening credits of the film appear on the screen, we can hear the voices of a group of black youngsters (as they repeatedly address themselves as "niggas") preparing to assault and kill another group of blacks for some previous affront we do not get to know about. The film's anxiety around this situation, apparently commonplace in the life in the hood, is clearly stated in the words that appear right after written over a black screen which reads "One out of 21 black American males will be murdered in their lifetime. Most will die at the hands of another black male". After the sound of the gunshots the police sirens fade out, the first shot of the film shows the image of a stop traffic-sign while, in the background, a plane flies above the rooftops of the hood.

By means of this simple symbol, the film not only demonstrates its ideology around the black-on-black violence as something to be stopped once and for all (Wiegman 1993: 183), but it also brings up the apparently insurmountable distance between their everyday lives in the hood and the world outside. Following Manthia Diawara's statement that "signs play an important role in limiting the movement of people in South Central Los Angeles" (1993: 22), I agree that the rest of the traffic signs in the film's prologue can become significantly noteworthy. The introductory scene, in which a group of ten year old boys (including an infantile version of Tre) go to a murder scene while they talk about a past night shooting, can be said to reveal the film's vision of this enclosed trapping environment as a definitory element in the formation of the 'hood individuals' present and future identities. While two successive "one way" traffic signs seem to direct the children's route around the "hood towards the crime scene, a big red sign that reads "wrong way" warns the spectator about the undesirable likelihood that following the 'hood ways' may end up with the boys' own death.

As Zigmut Bauman states in his book Liquid Modernity, ${ }^{6}$ it is a paramount aspect of nowadays' social structures that the elites in power hold a tight

\footnotetext{
6 Bauman's theories are, in turn, based on Michel Foucault's works, especially Discipline and Punish: The Birth of the Prison (1977).
} 
command over the mobility of the rest of the population. While the general population is denied the possibility of evading its own environment, these elites (in control of the means of transportation) are able to move freely across borders and exert their dominance invisibly from a safe distance (2000: 14-20). Whites and their remarkable nonattendance in the film can easily fulfil the role of those elites that Bauman called "absent landlords" (10). Deliberately omitted during most of the film, the visual representations of significant whites and their agency in the state of affairs that defines blacks' existence in the 'hood are foregrounded in some selected moments. For instance, all over the wall at the murder scene around which the children gather, gunned electoral posters of smiling Ronald Reagan wearing a cowboy hat remain impassive witnesses of black selfdestruction. At the same time, Reagan's representation in the guise of the United States iconically over-reproduced glorious past relates to the primal source of the glorification of violence in US American culture. The incongruous relation that the United States maintains with its own violent past, and the effect it bears on the current state-of-affairs, is again textually reinforced in the history class scene, when the children are taught the story behind Thanksgiving Day. Although the teacher presents the occasion as a symbol of communion between different races, and even rushes to correct herself and use the politically correct expression "Native Americans" instead of "Indians" in order to demonstrate certain diversity awareness, her speech seems to be historically and contextually unsound. The children's drawings that the camera focuses on while the teacher speaks are full of police officers and dead bodies, not only reflecting the incongruence between the black children's experience and the teacher's Eurocentric curriculum (Dyson 1993: 94), but also implicitly associate the violence of both, as the teacher, in an exercise of dominant reading of History, overlooks the eventual violent outcome of the clash between the Anglo-Saxon settlers and the native Americans.

Later, in one of the most judgemental scenes of the film, Furious, fulfilling the role of father and leader for the community ${ }^{7}$, is shown to give a speech about the importance for blacks to own their own houses, businesses and land if they are to fight the degradation of their life in the neighbourhood. With the objective of 'gentrifying' the neighbourhood, and instead of simply raising the standards of living and favouring in this way the upward mobility of their inhabitants, as Furious explains, the whites lower down the value of the houses through the omnipresence of guns, liquor, drugs and the lack of real resources

\footnotetext{
7 Furious' role in the film in fact, and specially enhanced in this scene, seems to resonate the figure of Martin Luther King Jr. as spiritual and ideological leader of the black community.
} 
to make a living in the hood. Then, their banks and firms buy the properties to speculate with them, selling the houses at a higher price to the whites when their original underprivileged inhabitants have been evicted (Smith, 2002: 438). ${ }^{8}$ The degradation of the standards of living in the 'hood is, according to Furious' resisting reading, just means for the whites' superstructures to make a profit out of their control over the mobility and reterritorialization of blacks and their eventual self-destruction". Once these "inner city communities are cut off from sources of moral authority and legitimate work" (Dyson 1993: 97), crime turns to be a viable and accessible way of living that most do not even consider questioning, even if it means to be constantly surrounded by delinquency and death.

As Bauman (2000: 13) explains, the implemented role for non-elite, forcedly sedentary individuals is plain demise at the service of a power which, clearly stated at the beginning of the film, does not even need to get its hands dirty. Moreover, the white-owned means of transportation that could fulfil the residents' desire for mobility are instead used to degrade even more their existence in the 'hood (ships and planes bringing drugs) or to ensure that they never get to leave their premises (surveillance police helicopters), reinforcing this way the hierarchical power relation they entail. As a postmodern version of Foucault's modern Panopticon, ${ }^{10}$ which Bauman also used in his argumentation, the constant sound of the invisible helicopters over the 'hood "works to keep the community in its place through the awareness and internalization of surveillance and perceived criminality" (Massood 1996: 91). The attendance to Furious' "sermon-on-the mount" speech (Wiegman 1993: 185) is in fact the only time, and already as adults, when the protagonists will be shown leaving the confines of their own surrounding, but only to visit the even more dangerous neighbourhood (of similar idiosyncrasy) of Comptom. This "dispute over agency

\footnotetext{
8 Socio-demographical researches on the development of postmodern city-scapes, carried out by authors like Mike Davis (2006) and Saskia Sassen (2006), pointed out the reversal migration that took place in LA in the second half of the $20^{\text {th }}$ century, by which the downtown became the home of the poorer neighbourhoods of the city, while the richer strata of society and the work moved to the suburbs at the outskirts of the city. However, as Smith (2002) explains, in later phases of the urban reterritorialization of big cities all around the world, gentrification has become the main way of "retaking the city for the middle classes" (443), evicting any kind of minority or under privileged group, and transforming whole areas along with their social character.

9 Here, the term 'superstructure' is used in line with Louis Althusser's understanding of it. According to him, capitalist societies are structured on two levels, an economic base, called infrastructure, and an ideological top, called superstructure, dominated by the economic elites in power (1971).

10 The idea of the 'Panopticon' that Foucault (1977) used to define modern power consists, in short terms, of a prison-like fortress in which the inmates are tied to the place and barred from all movement under the tight and constant surveillance of the guards above them.
} 
and control over the community" as Diawara (1993: 22) describes it, is portrayed to have an immense repercussion on the character's mobility in different realms. As it will be shown throughout the second part of the film, when the 'hood's children have already become young adults, it is not a mere issue of their geographical mobility that is at stake when agency is concerned, but a whole sense of socio-identitarian self determination and upward mobility.

The different levels of compliance with the idiosyncrasy of the life in the neighbourhood, and the personalities attached to it, are represented in a gradient and embodied by the different characters that surround the protagonist's life. At the negative end of the gradient Tre's friends, the 'boyz' stand. If we could see Doughboy (Baha Jackson/Ice Cube) being taken resignedly to the reformatory at the close of the first part of the film, then the first images in the second part depict a party in celebration for his return from jail, from where he seems to have been coming and going. This way, we are shown that the boyz' identities as delinquents, only hypothetically latent as children, have crystallized over the years without any apparent measure of resistance against it having been taken either by society or by themselves. Not only out of sheer carelessness, society's discourse seems to have done nothing but to force them into adjusting to that negative stereotypical pattern of action expected from them. All throughout their lives, even when not committing an offence, black males are represented as being violently harassed and insulted by the police; as children, disrespected and undermined by their own parents; as youngsters, attacked by elder gangs; and, as citizens, ignored completely by the media. With no other alternatives offered by society, delinquency becomes their only possible self-identificatory reality, "[their] world par excellence" (Berger and Luckman 1967: 36). Even going to the Army, the single option that the system seems to offer them outside of their neighbourhood, means just leaving proper society completely at a side and exchanging the violence of the hood for the violence of the state.

In Foucauldian terms, black males in the film, can be said to be "excluded" from proper society and from the agency over the discourse that defines it. ${ }^{11}$ Constantly seeing themselves through the eyes of others and their discourses, they epitomize the process that Erich Fromm defined as "authoritarian conformity", by which "the individual ceases to be himself; he adopts entirely the kind of personality offered to him by cultural patterns; and he therefore becomes exactly as all others expect him to be" (as cited in Penas Ibáñez 2006: 236). Their acceptance and identification with these patterns, attached to the

11 In Foucault's "The order of Discourse", exclusion is one of the main procedures, along with limitation and appropriation, by which dominant discourses are controlled and function (1981: 61-70). 
idiosyncrasy of their environment, means also the acceptance of their neighbourhood as a geographical and identitarian ghetto of which there seems to be no possible entrance or exit. Lies repeated often enough become truths, and the system's reliance on stereotypes works no differently. In their article "Social Groups and Social Stereotypes", Hewstone and Giles point out that stereotypes are always harder to contravene than to accept, even neurologically (1997: 280), and that even if part of fallacious representations, commonly shared stereotypes will eventually end up becoming real in their social consequences (270).

In this sense, several authors have noted the disrespectful, stereotypical and objectifying way in which Doughboy and the boyz address black women as 'bitch', 'ho' or 'hootchie', using them as scapegoats for their own frustrations (Wiegman 1993: 183; Dyson 1993: 93). However, they have overlooked first, the fact that black females are also portrayed using those terms between them, and second, that black males use a similar kind of language to refer to other black males. It has been demonstrated that context, race, gender, age and class have a huge impact on the threshold for what can be defined as verbal aggressiveness (Jay 2000: 160-161), and that blacks in particular engage in much more verbal play and bantering than whites. However, it is difficult to interpret their sub-standard African-American vernacular's preference for appellatives such as 'nigger', 'punk', 'fool', 'stupid' or 'motherfucker', terms by which the members of the gang refer to each other, as a case of in-group bonding. In fact, several instances can be found in the film in which these terms become what has come to be known as 'fighting words', that is, "personally provocative epithets spoken face-to-face to an individual that lead to immediate violence" (Jay 2000: 216). Verbal aggressiveness is portrayed in the film as the origin for the fight at the school, for the constant arguing between girls and boys in the 'hood, for the shooting at the Creenshaw Party and for Ricky's (Morris Chestnut) fighting his brother Doughboy, leaving his house and being eventually killed in a nearby alley. Especially remarkable is in this sense the pragmatics of the word 'nigger'. Coopted from the way in which whites referred to their black slaves in the past, the term is used carelessly by the gang for in-group communication, and very pejoratively by the harassing black police officer that patrols the 'hood. These different cases of linguistic "accommodation", as Howard Giles and Peter F. Powesland denominate it (1997), are said to also affect all levels of behaviour and entail an inevitable degree of identity-change (Penas Ibáñez 2006: 232). Language forces individuals into its patterns and presents the subject with a prefabricated understanding of the reality surrounding him (Berger and 
Luckman 1967: 53). I find likeable to think then, that black males addressing themselves as 'niggers', and black females referring to themselves as 'ho's', do nothing but accept and reproduce the autocratical and violent ideological standards that gave birth to them in the first place. Language, therefore, becomes not so much a "blueprint" of the character's identity (Penas Ibáñez 2006: 237), but a stigma signalling and perpetuating their role within the hierarchy of power.

However, language is not the only external sign of their conformity with the patterns that society's discourse has ready for them, but a part of the whole reenactment of their prearranged identities. Becoming what Ervin Goffman calls a "performative team" (1959: 79), the boyz in the 'hood carry out an almost dramaturgical interaction by which they stage their identities as gangsters constantly, especially in the presence of other 'teams'. As Goffman points out, performative interaction is always based on a "two-team interplay" (1959: 92) by which the other team fulfils the role of an audience, and whose opposition as outsiders enhances even more the first teams' representation of reality. Whether their audience is the other gang, their more successful friends and brothers, or the girls of the neighbourhood, the boyz' constant and antagonical opposition with other teams, becomes a direct projection of the same disdain they suffer in their own everyday lives. Inexorably permeated by society's discourse, the social interactions that these youngsters carry out, represent, reproduce and reinforce the stereotypical identities that they were expected to fulfil in the first place as inhabitants of the 'hood.

At the positive end of the spectrum of agency applied to geographical, social and linguistic mobility, we can find Tre's mother, Reva (Angela Basset). Assumedly divorced from Furious, middle-high class and educated, her apparent success seems to be a direct outcome of her leaving the hood. However, the nuanced representation that her ideals have in the film is far from utterly univocal. At the beginning of the film, right after Tre gets into a fight in class, she immediately sends him to live with his father in the neighborhood with no apparent regret. For the rest of the film, she will be another absent figure, with no visible interest in the development of her son's life until he is old enough to go to college. This rejection of not only her son, but her whole community and origins stays very much in tune with what Anthony Elliot and Charles Lemert define as "The New Individualism" and the disengagement between the individual and the collective that sustains it. Product of today's postmodern globalized and capitalistic society, this mentality is defined by an anxious search for self-fulfilment and a detachment from any interpersonal obstacles that could get in the way of the person's egocentric designs (2006: 3). Institutions like the 
neighbourhood, the family or the nation, already defined as "zombie institutions" by Beck (as cited in Bauman 2000: 12), are but impediments for the fulfilment of personal freedom. However, Elliot and Lemert (2006: 10) also point out, as Bauman had done, that this supposed freedom is only available to people of means, while poor people are just left behind under the stereotypical impression that "the poor simply do not know how to behave" (ibid). Reva not only fulfils this late modern capitalistic pattern by distancing herself from collective ideals to take the route of private success, but also in feeling the emotional hollowness that these practices entail. As much as could be said against the boyz, at least they demonstrate a sense of rooted belonging and a mentality of standing by and defending each other if necessary. ${ }^{12}$

As Stuart Hall points out, the complete overturning of a stereotype may simply mean an implicit acceptance of the categorical understanding of reality that gave way to it in the first place (1997: 272). Reva, in her complete rejection of the black community, and her ore-like adoption of the whites' ways, does not escape this way "the contradictions of the binary structure of racial stereotyping" (ibid) and the relation of assymentrical power and domination that they entail. Under this perspective, and even if his discourse may sound contradictory at times, Furious' character emerges as an oasis in-between extremes and as embodiment of the ideological liminality that the film wants to enhance. Breaking with the opposing positions that Reva and the 'boyz' symbolize, and through the saliency of Furious as a successful guide for the young, the film rejects the Kierkegaardian understanding of reality as a world of either/or, in favour of "an Afroncentric world of both/and" (Dyson 1993: 95). Furious works outside the neighbourhood, but remains living in it; rejects violence, but does not hesitate to protect what is his by any means necessary; is greatly educated, but his language sometimes deviates to less polished varieties and vocabulary. Even as father of Tre, "he is disciplined but loving, firm but humorous, demanding but sympathetic" (Dyson 1993: 96). Tre, under his father's guidance is taught to be responsible and hard-working and seems to follow the same path. He lives and has his friends in the neighbourhood, but works outside at the mall. By no means is he shown using the terms 'bitch' or nigger', but he does

\footnotetext{
12 The opposition between 'roots' and 'routes' as definitory elements of the individual's identity is constantly foregrounded in the film. While Reva clearly breaks with her origins in the community, her roots, in order to become a subject in her own terms, the boyz openly embrace them as the core of their identity. However, Furious and, by extension, Tre are shown trying to maintain certain equilibrium between both, rejecting a completely essentialist nature of black identity, but at the same time, respecting the relations background and traditions within which they grew up.
} 
swear when angry. And, although he feels the necessity of avenging Ricky's death, which would mean reproducing the prevailing vicious circle of violence, he is rational enough to reject that possibility.

The film's epilogue, in which Doughboy and Tre converse about their lives after the death of Ricky while we hear a surveillance helicopter flying above, very suitably serves to contrast both identities and approaches to black existence. Doughboy, after watching the news, seems to realize for the first time how little value their lives have for the elites in control of the media. In keeping with the mentality of the privileged in power, more concerned about global than local issues, the media do not mention even once the death of his brother. Violence, for them, seems to be an international problem, but apparently not an issue within their own national frontiers. As Doughboy states "either they don't know, don't show or don't care". At this point, Doughboy not only rejects bragging about having killed his brother's murderers, but he is shown digressing from his usual full-of-cursing variety of language, and actually speaking from the heart for the first time. However, his self-reflexive momentum also reveals how much of society's discourse has permeated Doughboy's identity when he carelessly states that "Shit just goes on and on... Next thing you know, somebody might try to smoke me. Don't matter though, we all gota go sometime uh?” Tre, facing Doughboys' resigned acceptance of his prearranged destiny, demonstrates his belief in the unity of the community by telling Doughboy that he still has a brother in him. Two weeks later, as the film tells us, Doughboy will actually be killed, and by fading his image out from the background, the films reveals how little relevance his life has had even for the overall social scheme of the hood. On the other hand, Tre will go to the university in Atlanta with his girlfriend. However, this escape from the neighbourhood's constrains, to which it could be arguably said that he is not coming back, also implies that, as long as things do not change, there is no real future for the black people remaining in the hood for good.

As its final statement and morals, the film uses Ice Cube's song "How to Survive in South Central", especially written for the film, to dismount violence as the solution to the 'hood's problems. Full of radical remarks such as "Rule number one: get yourself a gun", "you can't find shit in a handbook" or "Rule number two: don't trust nobody. Especially a bitch, with a hooker's body", the lyrics conspicuously contravene the film's ideology. By means of this contrast, the film contests the stereotypical images that Ice Cube's persona brings up as epitome of the black's experience in the 'hood. As we know by the end of the film, his profligate lifestyle, violent attitude and language, does not represent the way to actually survive in the hood, but mostly the opposite. In contrast, the film, through 
the character of Tre, enhances a "more culturally productive black masculinity" (Wiegman 1993: 182). In this aspect, the omniscient presence of the father figure of Furious, which finds no equivalence in the rest of the 'hood's families, is critical for Tre's development. While all the other youngster's fathers are conspicuously absent, as if reproducing the white dominant patterns within the black family, Furious' determination to remain with his son and in the neighbourhood is a fundamental element of his ideology. Defined by education, respect for each other, community spirit, responsibility and hard work, Tre's point of view is shown to be the only one capable of fighting social determinism and the place-biased criminal identities that every black subject is expected to fulfil within this system. In Singleton's film, as Dyson points out, "choice itself is not a property of autonomous moral agents acting in an existential vacuum, but rather something that is created and exercised within the interaction of social, psychic, political and economic forces of everyday experience" (1993: 95). Geographical, social and linguistic mobility are this way intermingled in the shaping of the black subject's identity, and only individuals willing, and allowed, to gain agency and control over them can overcome the stereotypes attached to their in-group and out-group image and achieve a certain degree of identitarian self-determination and freedom.

\section{REFERENCES}

Althusser, L. 1971. Lenin and Philosophy and Other Essays. New York: Monthly Review Press.

Bauman, Z. 2000. Liquid Modernity. Malden: Polity Press.

Berger, P. L. and T. Luckman. 1967. The Social Construction of Reality. New York: Doubleday-Anchor.

Diawara, M. 1993. "Black American Cinema: The New Realism". Black American Cinema. Ed. Manthia Diawara. New York: Routledge. 3-25.

Davis, M. 2006. City of Quartz: Excavating the Future in Los Angeles. London and New York: Verso.

Dyson, E. 1993. Reflecting Black: African-American Cultural Criticism. Minneapolis: University of Minnesota Press.

Elliot, A. and C. Lemert. 2006. The New Individualism. Abingdon: Routledge.

Foucault, M. 1977. Discipline and Punish: The Birth of the Prison. New York: Vintage.

Foucault, M. 1981. "The Order of Discourse". Untying the Text: A PostStructuralist Reader. Ed. Robert Young. London: Routledge. 48-78. 
Goffman, E. 1959. The Presentation of the Self in Everyday Life. New York: Doubleday-Anchor.

Giles, H. and P. Powesland. 1997. "Accomodation Theory”. Sociolinguistics. Eds. Nikolas Coupland and Adam Jarowski. London: MacMillan. 232-239.

Hewstone, M. and H. Giles. 1997. "Social Groups and Social Stereotypes". Sociolinguistics. Eds. Nikolas Coupland and Adam Jaworski. London: MacMillan. 270-283.

Hall, S. 1997. "The Spectacle of the "Other". Representation: Cultural Representations and Cultural Practices. Ed. Stuart Hall. London: Sage Publications. 223-290.

Jay, T. 2000. Why We Curse: A Neuro-Psycho-Social Theory of Speech. Philadelphia: John Benjamins.

Massood, P. J. 1996. "Mapping the Hood: The Genealogy of City Space in "Boyz N the Hood and Menace II society". Cinema Journal 35 (2): 85-97.

Penas Ibáñez, B. 2006. "The Signifiers of the Self: A Sociopragmatic Account of Linguistic Diversity and the Discursive Construction of Identities". Interculturalism: Between Identity and Diversity. Eds. Beatriz Penas Ibáñez and Carmen López Sáenz. Bern, New York: Peter Lang. 227-245.

Sassen, S. 2006. Cities in a World Economy. Thousand Oaks, London, New Dehli: Pine Forge Press.

Smith, N. 2002. "New Globalisation, New Urbanism: Gentrification as a Global Urban Strategy". Antipode 34 (3): 427-450.

Wiegman, R. 1993. "Feminism, 'The Boyz' and Other Matters Regarding the Male". Screening the Male: Exploring Masculinities in Hollywood Cinema. Eds. Steven Cohan and Ina Rae Hark. New York: Routledge. 173-193. 